\title{
The Regional Competitiveness of Hungary
}

\author{
Lu Huang1, Sezgin Hergül2 \\ ${ }^{1}$ Department of Business Administration, Jinan University, Guangzhou, China \\ ${ }^{2}$ Department of International Business, Poznan University of Economics, Poznan, Poland \\ Email: luhuang1989@gmail.com
}

Received 19 September 2014; revised 24 October 2014; accepted 7 November 2014

Copyright (C) 2014 by authors and Scientific Research Publishing Inc.

This work is licensed under the Creative Commons Attribution International License (CC BY). http://creativecommons.org/licenses/by/4.0/

\section{(c) (i) Open Access}

\begin{abstract}
This Report focuses on the regional competitiveness analysis of Hungary. Eight aspects are taken into consideration, which are Economics, Education and Learning, Innovation, Labor Market Efficiency, Infrastructure, Health, Farm, Environment Protection and Crimes. The final results show that Közép-Magyarország (Central Hungary) is the most competitive region which gets 68.46, while Észak Magyaroszág (Northern Hungary) which scored 24.23 is the least competitive region. Cultural and heritage, natural features, higher stage of urban/economic development, R \& D sector and high level business services are the main advantages of Közép-Magyarország (Central Hungary). However, for the least competitiveness region Észak Magyaroszág (Northern Hungary), more attention should be paid to infrastructure construction, labor mobility, institution efficiency, promotion of innovation, business environment, improvement of education and health and environment protection.
\end{abstract}

\section{Keywords}

\section{Regional Competitiveness, Hungary}

\section{Introduction}

In economic life and beyond, competition is one of the most fundamental sources of mobilization and creativity and it has immense impact on regional development and growth. As a collective term, competitiveness indicates the capability or tendency to compete under market conditions, the ability to gain and maintain economic positions in market competition, as shown by an increase in business success, market shares and profitability [1].

Hungary is a landlocked country located in the Central Europe with many neighbors-Slovakia to the north, Ukraine and Romania to the east, Serbia and Croatia to the south, Slovenia to the southwest and Austria to the west. Hungary's central location makes it a favorite destination for foreign investors who intend to expand their operations in Central and Eastern Europe. The country's telecommunications, transport and logistics infrastruc- 
ture, and the quality of education and life have attracted large amounts of foreign investment to Hungary in recent years. The official language of Hungary is Hungarian. The country became a member of the European Union in May 1st, 2004. EU accession brought both commercial and regulatory advantages. Becoming an EU Member State also brought a free trade system, the free movement of goods, services and labor, as well as capital [2]. In addition to all these advantages, another of Hungary's strengths is its well-qualified labor force. Due to the high standards of its education system, the country has a highly skilled and talented workforce, with professional foreign language skills and relatively low wage requirements. Although there is a great support from the European Union for regional development, some regions are lagging behind in economic development. Hungary's economically weakest regions are still at the tail end of Eurostat's list which illustrate inter-regional diversity in EU Member States.

This article aims at evaluating Hungarian regional competitive performance from a comparative perspective. The purpose of this paper is to apply the structural index concerning regional competitiveness in Hungary which enables to establish the competitive position of the Hungarian regions. The 7 regions, which correspond to the EU NUTS II level, will be ranked according to their competitive position in accordance with the model of regional competitiveness. Furthermore, the competitiveness ranking we used enables us to compare different components of competitiveness. This allows for a more detailed overview of the indicators contributing to regional competitiveness. The structure of the paper is as follows. The first section is a literature review of regional competitiveness. The second part concerns the research framework and the selection of regional competitiveness index which was applied in this paper. The third section is the data analysis part, which will present the general and each region's competitiveness analysis results. The final section provides conclusion and policy implications.

\section{Literature Review}

\subsection{Definition of Regional Competitiveness}

There were a number of attempts to define the idea of standard and extended competitiveness in the mid-1990s. Particularly important examples include the proposals put forward by the US Competitiveness Council, the OECD and the European Union. On the basis of various documents published by the OECD (1997), the Sixth Regional Periodic Report (EC 1999a) and the Second Cohesion Report of the EU (EC 2001a), the standard definition of competitiveness is as follows: "the ability of companies, industries, regions, nations and supra-national regions to generate, while being exposed to international competition, relatively high income and employment levels" [3].

Scientific literature suggests many definitions of a region, as it is used in a different context: geographic, cultural, political, economic, social etc. spheres. However, the regional competitiveness is the concept between the micro and the macro levels. A region is neither a simple aggregation of firms nor a scaled version of nations. The World Economic Forum (WEF) produces one of the best known competitiveness indices- the Global Competitiveness Index (GCI). The WEF definition links micro-(firm-level) to macro-(country-level) competitiveness. Meyer Stamer states that: "We can define (systemic) competitiveness of a territory as the ability of a locality or region to generate high and rising incomes and improve the livelihoods of the people living there" [4]. In contrast to the WEF definition focused on the concept of productivity, this definition is based entirely on the benefits to people living in a region [5]. Along the same lines in our paper, we adopt a definition of regional competitiveness which integrates the perspective of both firm and of residents [5] [6]: Regional competitiveness can be defined as the ability to offer an attractive and sustainable environment for firms and residents to live and work. Because these definitions cover issues which benefit both firms and residents, such as good institutions, and issues where their interests may conflict, such as wages, we try to balance the most important aspects of an attractive environment by combining the goals of commercial success with personal well-being.

For the definition of region, the literature raises two issues related to the selection of the appropriate regional level. First, competitiveness should be calculated for functional economic regions. The second is that the region should have an important political and administrative role. In most countries, however, functional regions are not administrative and vice-versa. In this paper, we focuses on NUTS 2 regions in the European Union. NUTS 2 regions are administrative or statistical regions which do not take into account functional economic links.

\subsection{The Measurement of Regional Competitiveness}

As discussed above, the complexity in defining competitiveness leads to difficulties in its measurement. Never- 
theless, there are examples of well-established studies which apply specific methods for the measurement of the level of competitiveness at national and at regional level.

At the country level, the Global Competitiveness Index, prepared by the World Economic Forum [7] and the World Competitiveness Yearbook by the Institute for Management Development are the most influential and best known indices. The GCI is intended to measure competitiveness at the national level, taking into account both micro- and macroeconomic foundations of competitiveness. It covers a large amount of countries, a total of 131 economies in 2007, and is based on over 100 indicators which describe 12 major pillars of competitiveness. The 12 pillars are institution, infrastructure, macro-economy, health and primary education, higher education and training, goods market efficiency, labor market efficiency, financial market sophistication, technological readiness, market size, business sophistication and innovation. The 12 pillars taken into account are described by a variety of observable qualitative and/or quantitative variables (indicators). Each pillar is described from a minimum of 2 variables (Market size) to a maximum of 18 variables (Institutions) [7] [8].

The World Competitiveness Yearbook (WCY) is an annual report on the competitiveness of countries, published since 1989 by the Institute for Management Development, a not-for-profit foundation located in Switzerland. It analyses and ranks the ability of countries to create and maintain an environment which sustains the competitiveness of enterprises. The WCY identifies four main competitiveness pillars (factors): economic performance, government efficiency, business efficiency and infrastructure. Each of these pillars is broken down into five sub-pillars (sub-factors) which describe different facets of competitiveness, for a total of 20 sub-pillars [9].

To improve the understanding of territorial competitiveness at the regional level, the European Commission has developed the Regional Competitiveness Index-RCI—which shows the strengths and weaknesses of each of the EU NUTS 2 regions. RCI was first published in 2010 as the result of a coordinated action between the Joint Research Centre and the Directorate-General for Regional Policy. The index development started in 2008 and builds on the methodology developed by the World Economic Forum for the Global Competitiveness Index. It covers a wide range of issues related to territorial competitiveness including innovation, quality of institutions, infrastructure (including digital networks) and measures of health and human capital [5].

The pyramidal model of regional competitiveness seeks to provide a systematic account of these means and to describe the basic aspects of improved competitiveness. The 'pyramidal model' of regional competitiveness: the components of long-term success are to be found in the base, the middle layer is constituted by the development (programming) factors, the basic categories included in the standard definition of revealed competitiveness are located one level higher, while the standard of living and welfare of the region's population, the ultimate objective, forms the peak of the pyramid [10] [11].

Besides international studies on regional competitiveness, in the past years several country specific analyses on the topic were published. They also represent valid attempts to describe regional competitiveness with an overall perspective and sound methodology, for example the United Kingdom, Croatia and Finland etc. [12][15].

\section{Research Framework}

In order to assess the overall picture of regional competitiveness and measure the level of competitiveness of Hungarian regions, our index adopted two methodologies based on the Global Competitiveness Index-GCI developed by the WEF and the European Competitiveness Index-ECI developed by the European Commission. For the European Competitiveness Index, to a large extent adopts and builds upon the methodology of GCI [6]. These indexes form a composite picture of how Hungary regions are performing and highlight the weaknesses, strengths and disparities that exist across Hungary in terms of many perspectives.

Eight aspects are taken into consideration, which is Education and Learning, Innovation, Labor Market Efficiency, Infrastructure, Health, Farm, Environment Protection and Crimes. These factors can be divided into three group. According to ECI, they are classified into three major groups as below Figure 1: (I) Basic, (II) Efficiency and (III) Innovation. Each RCI dimension as a simple arithmetic average of the transformed and normalized indicators have passed the "PCA test" [6]. The three groups are purportedly linked: The basic pillars represent the basic drivers of all economies. These pillars are most important for less developed regions. Efficiency plays a more important role for intermediate and especially for highly developed regions; a good performer in the Innovation group is expected to also be a good performer in the Efficiency and the Basic groups as 


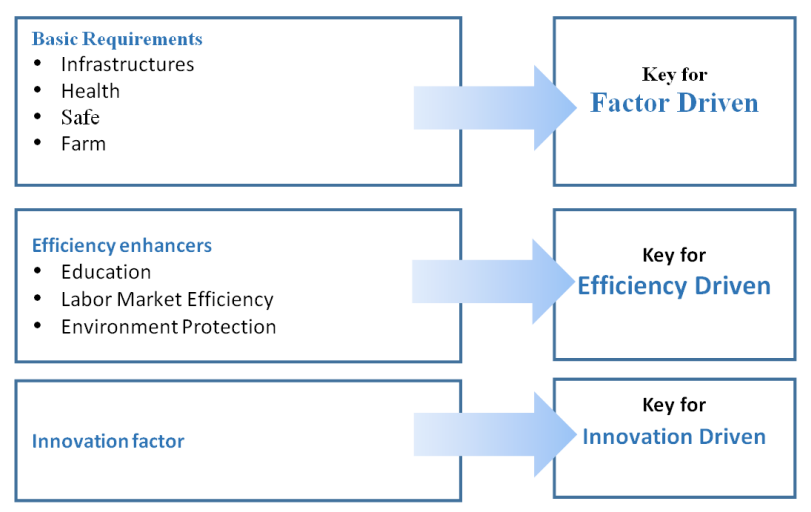

Figure 1. The pillars of Competitiveness.

they are instrumental to increasing levels of competitiveness.

The evaluation of each indicators as below:

Infrastructures: Stock of vehicles; percentage of total households with access to broadband; percentage of Individuals regularly using the Internet;

Health: Hospital beds; Healthy life expectancy;

Safe: Crimes recorded by the police;

Farm: Key Farm Variables;

Education: Education indicators; Population 25 - 64 with higher education; early school leavers;

Labor Market Efficiency: Employment rate; Labor productivity;

Environment Protection: Share of Renewable Energy in Final Energy Consumption;

Innovation: Patent applications to the EPO by priority year; Total intramural R \& D expenditure; Human Resources in Science and Technology;

Most of the individual variables forming the composite indicators have different measurement units, in order to normalize the variables and make them comparable, the "zero-notarization" method (min-max) were applied. $W_{i}^{k}$ is the normalized value of variable $k$ for region $i ; x_{i}^{k}$ is the value of variable $k$ for region $i$; $\min _{i \in I}\left\{x_{i}^{k}\right\}$ is the minimal value of variable $k$ in the group of regions $i ; \max _{i \in I}\left\{x_{i}^{k}\right\}$ is the maximal value of variable $k$ in the group of regions $i$.

For stimulants

$$
W_{i}^{k}=\frac{x_{i}^{k}-\min _{i \in I}\left\{x_{i}^{k}\right\}}{\max _{i \in I}\left\{x_{i}^{k}\right\}-\min _{i \in I}\left\{x_{i}^{k}\right\}}
$$

For DE stimulants

$$
W_{i}^{k}=\frac{\max _{i \in I}\left\{x_{i}^{k}\right\}-x_{i}^{k}}{\max _{i \in I}\left\{x_{i}^{k}\right\}-\min _{i \in I}\left\{x_{i}^{k}\right\}}
$$

The next step consists of computing the scores for the three groups of dimensions-Basic, Efficiency and Innovation - as arithmetic means of the dimension scores. For each region $i$ the sub-scores associated to the dimension groups are:

$$
\operatorname{RIC}_{\text {sub-score }}(i)=\frac{1}{n} \sum_{j=1}^{n} \operatorname{score}(i, j)
$$

In the last step, the RCI score is computed as weighted average of the three sub-scores. The set of weights is chosen according to the development stage of the region, allowing for an increasing relevance of innovative dimensions as the capability of the region increases (in terms of GDP per head). This basically means that a low score on the innovative sub-score counts more for high developed regions than for low developed ones. According to the GDP development of Hungary, Global Competitiveness Report 2012-2013 assigned weights for 
these three stages. Basic requirements accounts for 27.4\%; Efficiency enhancers is $50.0 \%$ and Innovation factors is $22.6 \%$ [16].

\section{Competitiveness of the Hungarian Regions}

Since 1996, Hungary has divided into 7 regions for statistical and economical purposes in order to meet the EU requirements. These seven regions correspond to NUTS 2 level units of Hungary. The regions are as the Figure 2 shows [17]: Közép-Magyarország (Central Hungary), Közép Dunántúl (Central Transdanubia), Észak Alföld (Northern Great Plain), Észak Magyaroszág (Northern Hungary), Dél Dunántúl (Southern Transdanubia), Dél Alföld (Southern Great Plain) and Nyugat Dunántúl (Western Transdanubia).

In this paper data of essential measures were gathered from Eurostat and Central Statistical Office source. We identified the crucial variables required to assess the regional competitiveness and to rank regions according to the competitiveness scores as below:

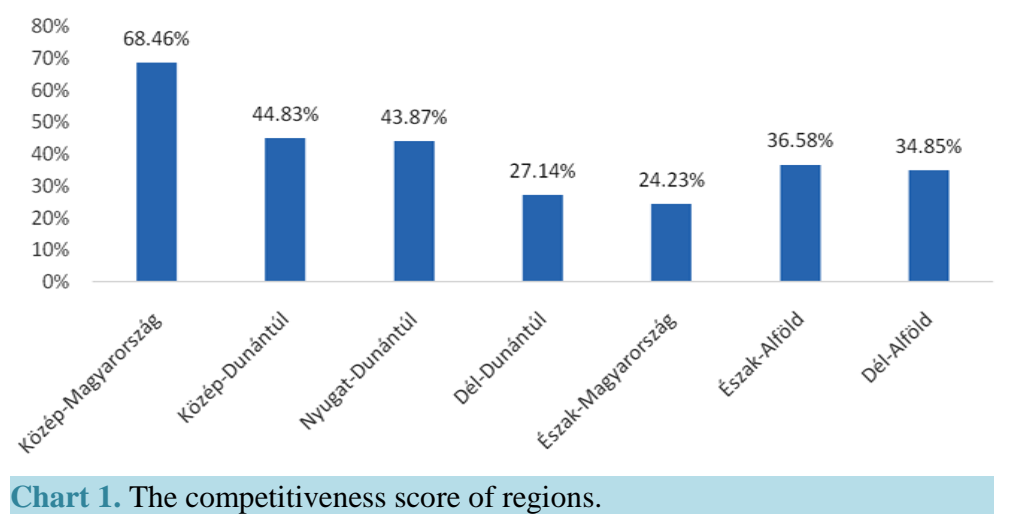

In general, the competitiveness development situation in Hungary can be divided into 4 levels. The top level is the region of Közép-Magyarország (Central Hungary), which is the most competitive region with the score of 68.46. The second level is the region of Közép Dunántúl (Central Transdanubia) and Nyugat Dunántúl (Western Transdanubia) with the scores of 44.83 and 43.87 repectively. Észak Alföld (Northern Great Plain) and Dél Alföld (Southern Great Plain) are belong to the third level, which with the scores of 36.58 and 34.85 repectively. While Dél Dunántúl (Southern Transdanubia) and Észak Magyaroszág (Northern Hungary) scored 27.14 and 24.23 repectively are the least competitive regions.

These regional competitiveness scores indicate the big gap and unbalanced development between regions. There are substantial economic disparities between them.

Közép-Magyarország, Central Hungary: Having 16.200 EUR per inhabitant. ${ }^{1}$ The capital city Budapest is situated in this region. With the strong support of capital economy, Central Hungary consists $38.5 \%$ of economic activity in Hungary. Industrial output shows some increase. Large part of the total industrial production (28\%) comes from this territory. Besides some districts in the capital, the level of unemployment is the second lowest in the county $(9.2 \%){ }^{2}$

Közép Dunántúl, Central Transdanubia: This region exceeds the national average when it comes to economical figures. GDP per capita in ths region is 8.700 EUR. 10\% of the economical activity is situated in this region. This is the second most industrialized region in Hungary taking the place behind the central region. Central Transdanubia generates $22 \%$ of the total industrial production. Unemployement in this region is $9.8 \%{ }^{3}$

Nyugat Dunántúl, Western Transdanubia: The total of 9.8\% of the economical activity located in this region. The GDP per capita in this region accounts 10.100 EUR which ranks the second place. The unemployment rate in this region is $7,4 \%$ which is the lowest in the country.

Észak Alföld, Northern Great Plain: This region carries the $11.4 \%$ of the economic activity. They produce 9.1\% of the total industrial product, thus ranks the 4th place. Their GDP per capita is calculated as 6.300 EUR in 2011. Unemployement rate is $13.9 \%$ which is the second highest after Northern Hungary region.

\footnotetext{
1“GDP Per Capita in NUTS2 level regions in Hungary”, Eurostat, Retrieved on 9th of June, 2014.

${ }^{2}$ Assembly of European Regions (2013) Regionalism Report on Hungary, p. 2.

3“Northern Hungary Region”, Hungarian Investment and Trade Agency, Retrieved on 9th of June 2014.
} 


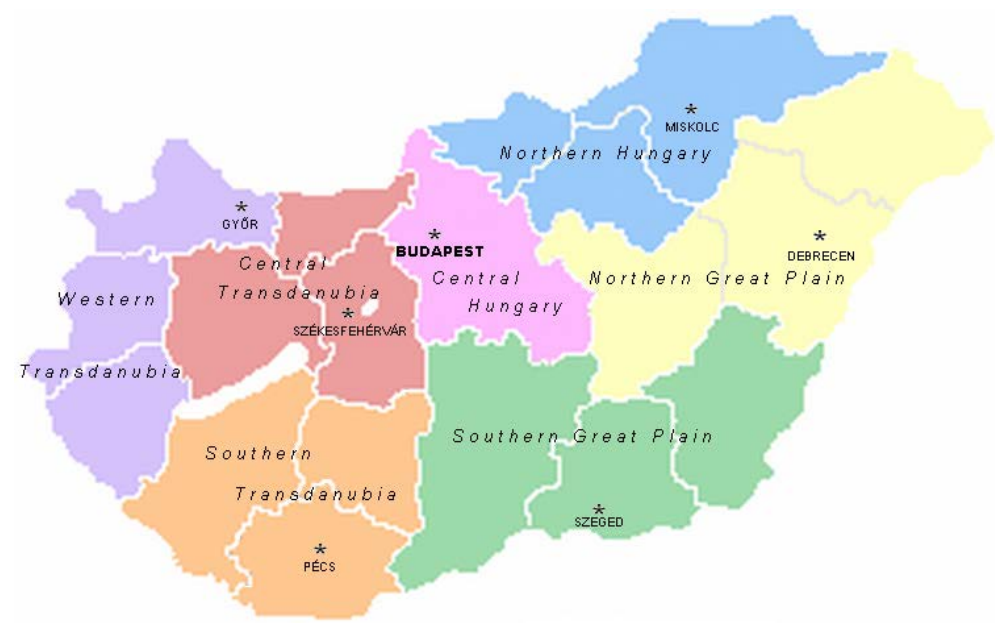

Figure 2. Regions and counties in Hungary.

Dél Alföld, Southern Great Plain: This region houses almost 12\% of the economical activity. The GDP per capita in this region accounts 6.500 EUR. The unemployment figure is $10.5 \%$.

Dél Dunántúl, Southern Transdanubia: This region houses more than $9 \%$ of the economic activity in the country. This region has a GDP per capita in the amount of 6.600 EUR. The interesting thing about this region is that despite the fact that their industrial production and distribution expanded by $15 \%$ - 20\%, the unemployment rate is above the national average $(12 \%)^{2}$

Northern Hungary, Észak Magyaroszág (Borsod-Abaúj-Zemplén, Heves, Nógrád County): In the case of economical activitiy 9\% of economical activity is registered in this region. The GDP per capita in this region is 5.900 EUR which is the lowest. Sales volume and industrial output is far below the national average. This region has the highest unemployment rate (16,6\%). As the least competitive region, Northern Hungary (Észak Magyaroszág) has the lowest GDP per capita with the amount of 5,900 EUR. Nowadays, recent activity of FDI (Vodafone, BOSCH etc.) helps region to develop more. The companies located there mainly belongs to the sectors of machine industry, automotive industry, agricultural machinery, food industry, rail vehicle industry and chemical and pharmaceutical industry.

\section{Conclusions}

In conclusion, Hungary has 7 regions on NUTS 2 levels, they are: Közép-Magyarország (Central Hungary), Közép Dunántúl (Central Transdanubia), Észak Alföld (Northern Great Plain), Észak Magyaroszág (Northern Hungary), Dél Dunántúl (Southern Transdanubia), Dél Alföld (Southern Great Plain) and Nyugat Dunántúl (Western Transdanubia).

We conduct regional competitive analysis. The final result showed that Közép-Magyarország (Central Hungary) is the most competitive region which gets 68.46, while Észak Magyaroszág (Northern Hungary) scored 24.23 is the least competitive region. The economies of the other regions have stagnated. The performance of these regions also show an unbalanced development situation, and have been found to be catching up more and more with their Western counterparts (especially the region of Central Hungary).

Rich cultural and built heritage, local natural features, the potential of the tranquil living environment, higher stage of urban/economic development, R \& D sector and high level business services are the main advantages for well developing of Közép-Magyarország (Central Hungary). For the least competitiveness region Észak Magyaroszág (Northern Hungary), future measures should be taken towards infrastructure construction, labor mobility, institution efficiency, promotion of innovation, business environment, improvement of education and health and environment protection [17].

\section{References}

[1] Lengyel, I. (2000) A regionális versenyképességről [Regional Competitiveness]. Közgazdasági Szemle (Economic Review-Monthly of the Hungarian Academy of Sciences), 47, 962-987. 
[2] PWC (2014) Investing Guide Hungary 2014.

[3] Europea, C. (2001) Second Report on Economic and Social Cohesio, Luxembourg.

[4] Meyer Stamer, J. (2008) Systemic Competitiveness and Local Economic Development. Meso Partner, Duisberg.

[5] Paola, A. and Lewis, D. (2013) EU Regional Competitiveness Index RCI 2013.

[6] Dijkstra, L., Annoni, P. and Kozovska, K. (2011) A New Regional Competitiveness Index: Theory, Methods and Findings. European Union Regional Policy Working Papers No. 2.

[7] Schwab, K., Porter, M.E. and Sala-I-Martin, X. (2007) The Global Competitiveness Report 2007-2008, Palgrave Macmillan Basingstoke.

[8] Sala-I-Martin, X., Blanke, J., Hanouz, M.D., Geiger, T., Mia, I. and Paua, F. (2007) The Global Competitiveness Index: Measuring the Productive Potential of Nations. The Global Competitiveness Report, 2008, 3-50.

[9] IMD (2012) World Competitiveness Yearbook. International Institute for Management Development, Lausanne.

[10] Lengyel, I. (2004) The Pyramid Model: Enhancing Regional Competitiveness in Hungary. Acta Oeconomica, 54, 323342. http://dx.doi.org/10.1556/AOecon.54.2004.3.3

[11] Gardiner, B., Martin, R. and Tyler, P. (2006) Competitiveness, Productivity and Economic Growth across the European Regions. Regional Competitiveness, 30, 55.

[12] Huggins, R. and Thompson, P. (2010) UK Competitiveness Index 2010. Centre for International Competitiveness, UWIC, Cardiff.

[13] Annoni, P. and Kozovska, K. (2010a) EU Regional Competitiveness Index. Luxembourg, European.

[14] Annoni, P. and Kozovska, K. (2010b) EU Regional Competitiveness Index. Luxembourg, European.

[15] Huovari, J., Kangasharju, A. and Alanen, A. (2001) Constructing an Index for Regional Competitiveness, PTT.

[16] Schwab, K. and Sala-I-Martin, X. (2012) Insight Report: The Global Competitiveness Report 2012-2013. World Economic Forum, Geneva.

[17] Lagendijk, A. (2005) Regionalization in Europe. Stories, Institutions and Boundaries. Bordering Space, 77-92. 
Scientific Research Publishing (SCIRP) is one of the largest Open Access journal publishers. It is currently publishing more than 200 open access, online, peer-reviewed journals covering a wide range of academic disciplines. SCIRP serves the worldwide academic communities and contributes to the progress and application of science with its publication.

Other selected journals from SCIRP are listed as below. Submit your manuscript to us via either submit@scirp.org or Online Submission Portal.
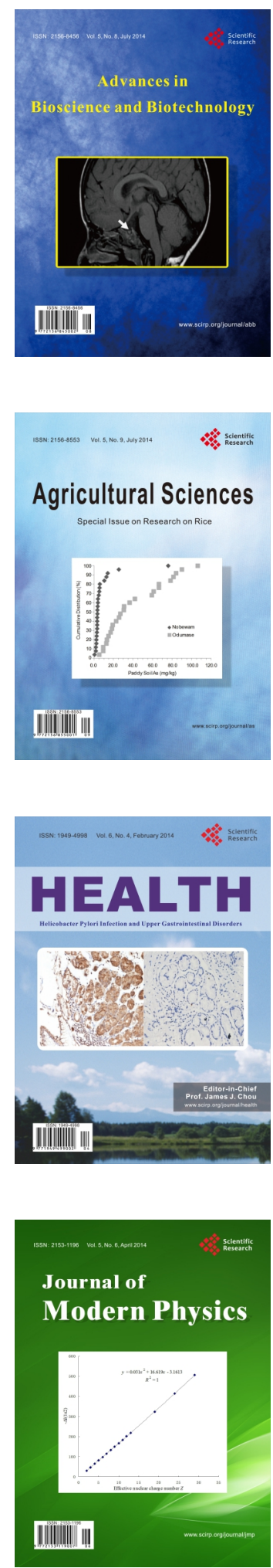
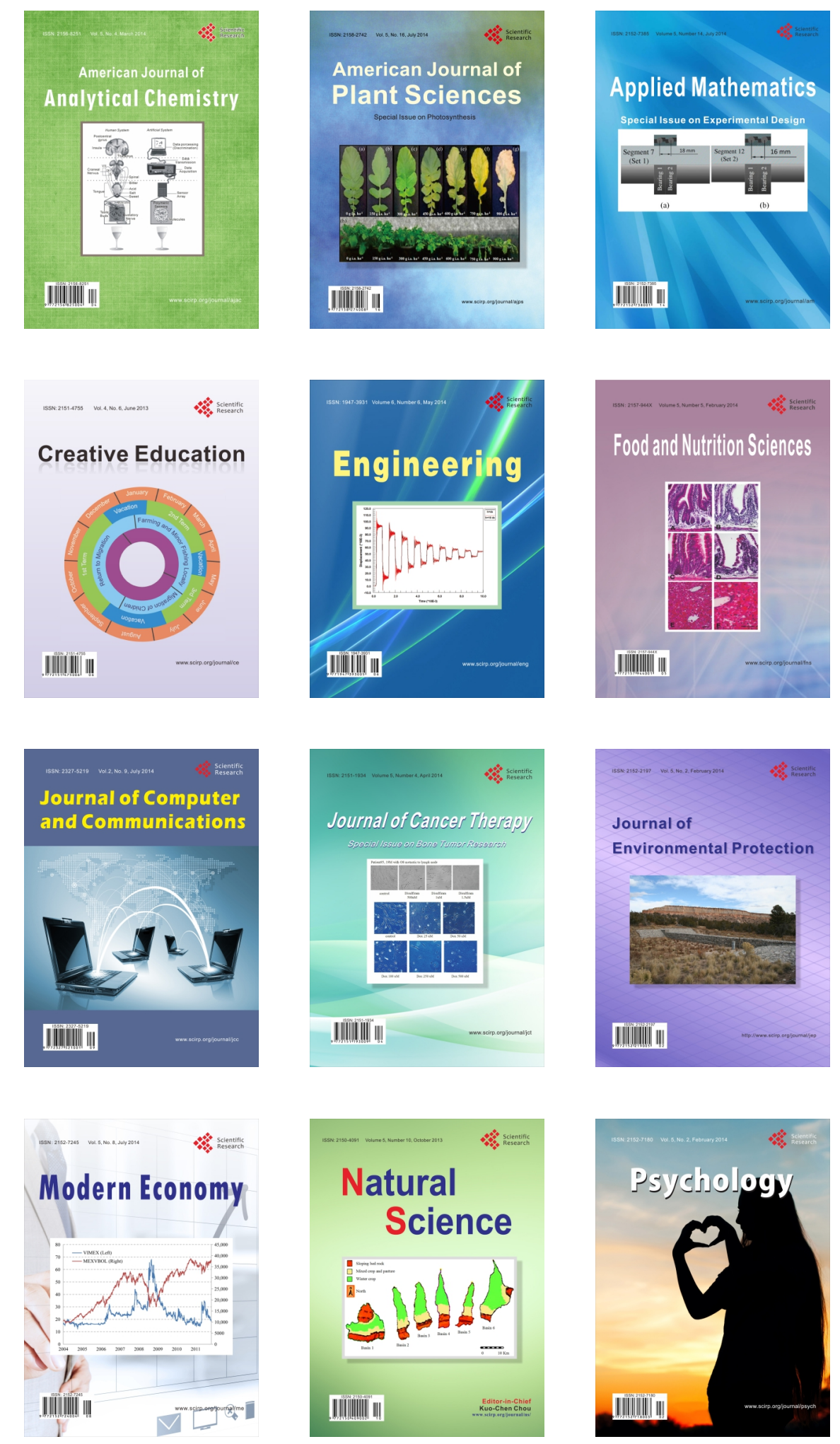